\title{
Public-Private Partnership as a Tool of Sustainable Development in the Oil-Refining Sector: Russian Case
}

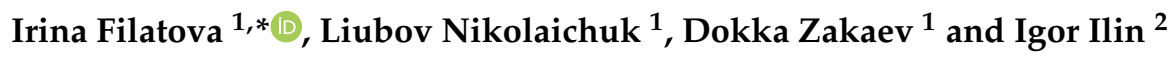 \\ 1 Department of Economics, Organization and Management, Saint Petersburg Mining University, \\ 199106 St. Petersburg, Russia; Nikolaychuk_LA@pers.spmi.ru (L.N.); dokka_zakaev@mail.ru (D.Z.) \\ 2 Higher School of Business and Management, Peter the Great St. Petersburg Polytechnic, University Federal \\ State Autonomous Educational, 195251 St. Petersburg, Russia; igor.ilin@spbstu.ru \\ * Correspondence: filatova_ii@pers.spmi.ru; Tel.: +7-911-199-1875
}

Citation: Filatova, I.; Nikolaichuk, L. Zakaev, D.; Ilin, I. Public-Private Partnership as a Tool of Sustainable Development in the Oil-Refining Sector: Russian Case. Sustainability 2021, 13, 5153. https://doi.org/ $10.3390 /$ su13095153

Academic Editor: Giovanni De Feo

Received: 26 March 2021

Accepted: 30 April 2021

Published: 5 May 2021

Publisher's Note: MDPI stays neutral with regard to jurisdictional claims in published maps and institutional affiliations.

Copyright: (c) 2021 by the authors. Licensee MDPI, Basel, Switzerland. This article is an open access article distributed under the terms and conditions of the Creative Commons Attribution (CC BY) license (https:/ / creativecommons.org/licenses/by/ $4.0 /)$.

\begin{abstract}
Dramatic changes in the global energy market due to COVID-19 pandemic, the OPEC + agreement, and increasing rates of green energy share in the world community have brought negative effects on the oil sector. In the long term, oil will reduce its importance as an energy resource, but for many years, it will continue to play a significant role in the world of energy. The oil industry has huge potential in terms of technical expertise, management, and financial resources to reduce its greenhouse emissions and ensuring an affordable availability of predictable energy. However, nowadays this sector has lost investing attractiveness. It is an interdisciplinary problem with a solution at the intersection of different stakeholders' interests. The article is a review one and devoted to the issue of the implementation a public-private partnership (PPP) as a key tool that allows the use of the state and the business' available resources to achieve the sector's sustainable development and investment attractiveness. Research and analysis of PPP were based on foreign and domestic literature, using classification and generalization methods, retrospective and critical analysis. This paper contains identified groups of drivers, constraints, and recommendations for further successful PPP implementation in the Russian case.
\end{abstract}

Keywords: investments; oil-refining sector; public policy; energy and resources policy; public-private partnership (PPP); Russia; sustainable development; synergetic effect

\section{Introduction}

The oil-refining industry is the backbone of livelihoods for people and industries around the world. One of the global challenges to the sustainable development of the oil-refining industry was the Paris Agreement within the United Nations Framework Convention on Climate Change in 2015. As a result, the tendency to displace fossil energy sources from the fuel and energy balance of many countries has intensified [1,2]. Nowadays, raw hydrocarbon materials are less attractive because of increasing greening in the world community $[3,4]$. The inter-fuel competition with alternative energy sources leads to stricter requirements for oil-refining products and sets the main pace and direction for the development of the oil-refining industry, for example, the petrochemical industry being approached as a source of new, environmentally friendly solutions for the oil-refining sector. Thus, a trend is aiming at reducing the sulfur content, introducing "clean" oil conversion systems [5], as well as minimizing the negative impact on the environment, requiring refineries' modernization by introducing high-tech equipment, which, in turn, requires significant investment in the oil-refining industry [6,7].

The efficiency of the oil-refining industry is very sensitive to changes in consumer demand. Therefore, the OPEC+ agreement to reduce oil production has affected oil consumption, the COVID-19 pandemic has resulted in the decrease of global demand for petroleum products (gasoline, kerosene, diesel fuel, jet fuel, and other by-products used, 
for example, for the production of plastic), and finally it has affected oil and oil products' price (Figure 1).

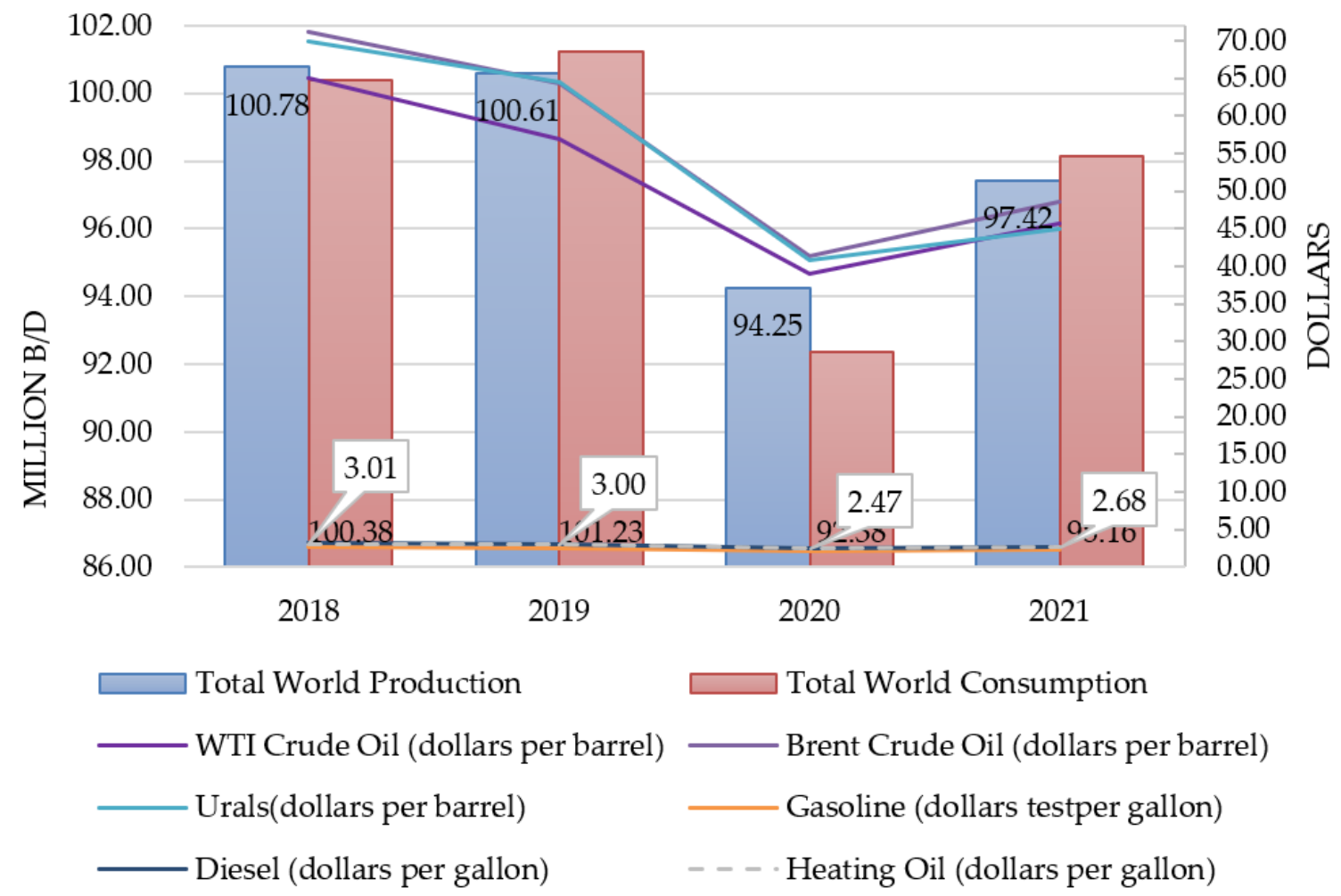

Figure 1. Oil in 2018-2021: tendency of world consumption, production, and prices. Source: compiled by the authors: Total World Production and Consumption [8,9]; Prices: WTI (West Texas Intermediate), Brent, Diesel, Gasoline, Heating Oil [8]; Price for Urals 2018 [10]; for 2019 [11]; forecast for 2021 based on [12].

Both factors, the pandemic and the OPEC+ agreement, have led to losses and reducing efficiency in the oil-refining sector in 2020. A refinery's economics is ultimately simple: it thrives on the price difference between crude oil and fuels like gasoline, earning a profit that is known in the industry as a cracking margin, which is quite low due to mentioned factors [13]. The world experts' forecasts, such as that of the Vice President-Oil Markets \& Downstream consulting, IHS Market Spencer Welch, are not comforting: "the profit from oil refining in the next five years will be less than the average for the last five years..." [14].

However, it is worth noting that oil will continue to play a significant role in the world of energy for many years to come (Figure 2).

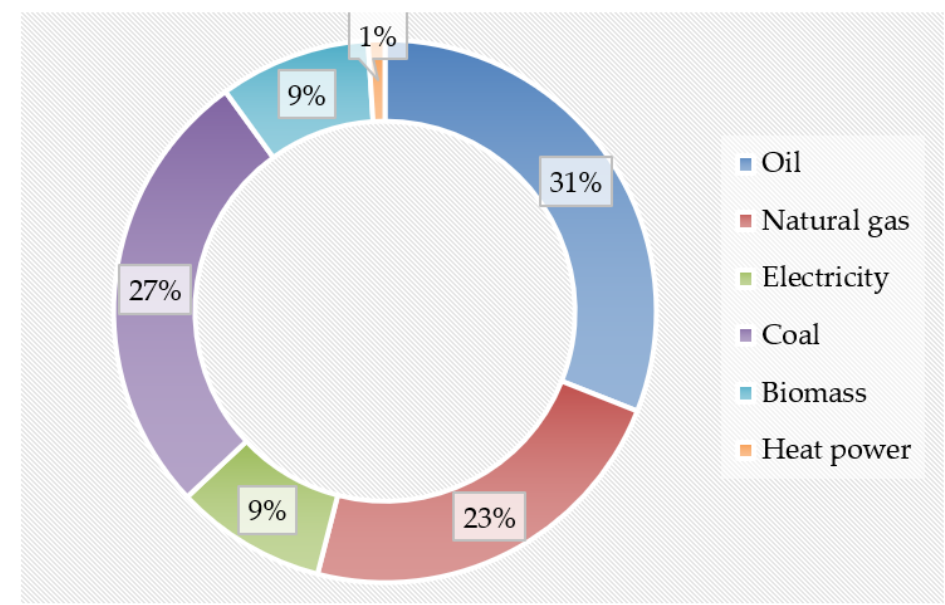

Figure 2. Total world energy consumption, 2019. Source: compiled by the authors based on [15]. 
According to this chart, oil takes up 31\% of the world's energy consumption. Moreover, the world's refining capacity is 5.1 billion tons and it is growing steadily at an average rate of $1 \%$ per year (Figure 3 ).

6000

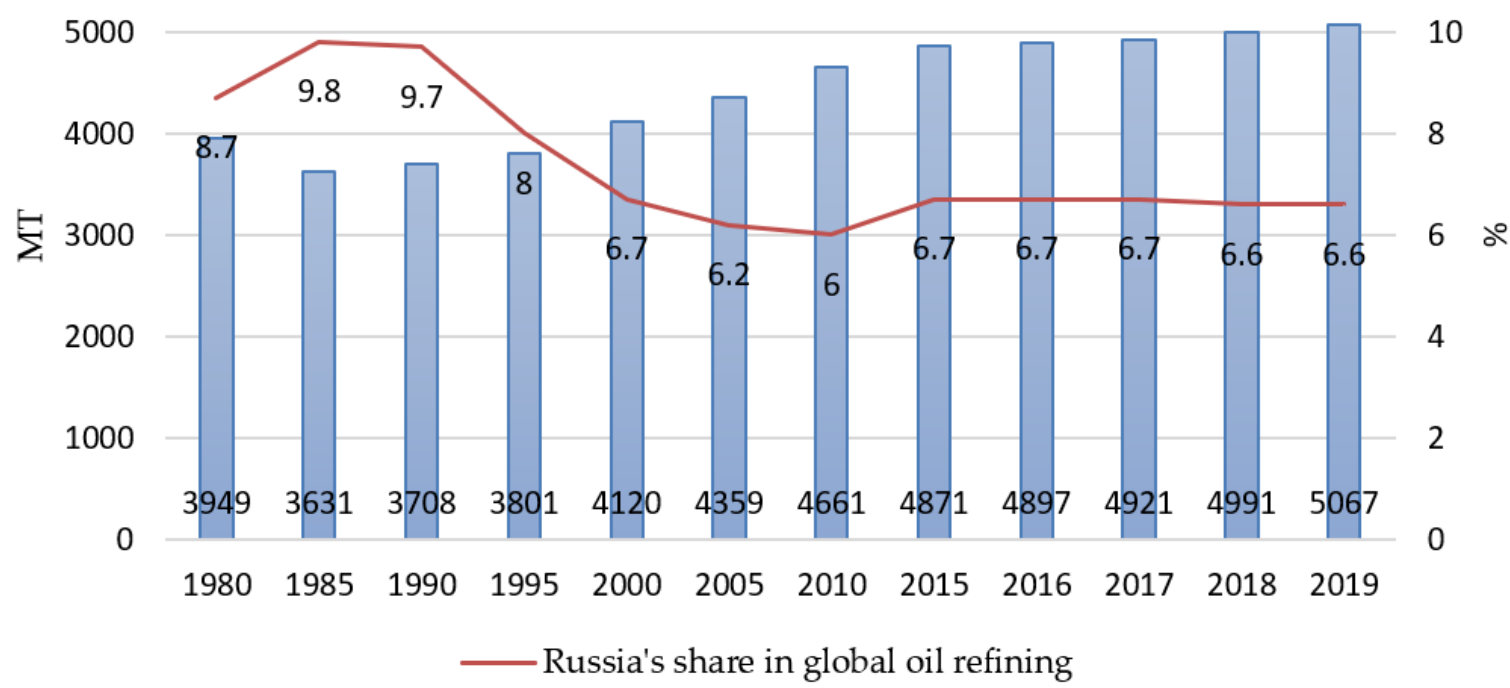

Figure 3. Dynamics of oil-refining capacities in the world, 1980-2019. Source: modified by the authors based on [16].

Russia holds a share of $6.6 \%$ and ranks third after the United States (18.7\%) and China $(16.0 \%)$. However, the existing high volatility of prices on the oil and oil products market, especially after the OPEC+ agreement and COVID-19 pandemic, as well as instability regarding the future development of the sector, negatively affects the investment attractiveness of the oil-refining industry as a whole, and, particularly, for the Russian's refineries. Presently, the Russian oil-refining industry is characterized by insufficient volumes of secondary oil refining, selling low value-added products to the domestic and foreign markets, lagging in technological development. Many projects are partly frozen because of the changes mentioned above. The main reasons are the prolonged duration of projects, high risks and demand of significant investments for development and modernization.

As a possible way of decision, we suggest introducing changes in the relations between the government and the business community within the framework of the public-private partnership mechanism (hereinafter referred to as PPP). Therefore, the purpose of this work is to study the PPP mechanism based on world experience and expand it, taking into account the Russian specifics of the oil-refining sector, for further implementation. Practically speaking, this will enable the development of a synergetic effect between the government and the business to balance the interests of all stakeholders, as well as to achieve oil refineries' sustainable development, which involves higher efficiency and minimizing negative factors caused by current technological, economical, and institutional conditions in Russian oil-refining sector.

As the concept of this article is a review one, it includes five sections. Section 2 is dedicated to public-private partnership literature review. Section 3 describes the methodology of this study. Section 4 includes four subsections that are devoted to discussion and results of the problem statement. Lastly, Section 5 highlights conclusion remarks of the study and further research directions that are based on the results obtained herein.

\section{Literature Review}

This research began with the selection of appropriate databases (Scopus, Research Gate, Google Scholar) and keywords, followed by a selection of journals and articles, categoriz- 
ing articles by stages, and then analyzing the articles taking into account the prospects for the possibility of adapting the described PPP mechanisms to the Russian oil-refining sector.

The PPP literature published from 1995 to 2016 was chosen using the approach of previous researchers $[17,18]$. Tang et al. considered PPP projects that were focused on the construction industry based on empirical and non-empirical studies, then further grouped them under different themes [19]. Wang et al.'s studies are limited to the area of public administration [20].

We have classified the articles into two main groups: theoretical and practical ones, dating since 1995. This year was chosen because, during that time, PPP had begun to expand significantly worldwide, even though the World Bank considered 1996 as the start of expansion [21]. So, back in 1995, the main issue was raised by researcher Brodie, M.J.: "the government as partner-bane or benefit?" [22]. This question was also analyzed later $[23,24]$ and remains an open one. In 1996, the author Grant presented an article revealing the key points of the successful implementation of PPP in Canada [25]. In 1997, researchers Gentry B. and Fernandez, L. presented the common themes and practical examples of urban water supply under the development of public-private partnerships at the OECD seminar on globalization and the environment in Paris [26]. In 1998, a year later, the PPP tool was used in a tunnel project in China [27]. In 1999, the PPP mechanism effectiveness was approved due to the fact of its implementation for transportation system [28].

In 2004, Hall D., continuing studies of the PPP mechanism, noted in his works factor constraints for the development of PPP: the bureaucratic mentality of civil workers contradicts the mindset of private-sector workers [29]. The same topic has formed the basis of modern research. Thus, according to Patibandla, public-private partnership is a huge potential for the infrastructure sector, but the author also noted significant differences in the way of workers' thinking in the public and private sectors [30]. The main literature on the studying subject reports cases of "significant divergence" in opinion between the public and private sectors, leading to a stalemate or collapse of the PPP mechanism in developing economies around the world [30-32]. A World Bank Study found that 90\% of project failures have been caused by a lack of coordination between public and private partners on infrastructure projects [33]. The potential threat was identified as rising costs [32] and failure to provide value versus taxpayer money shortages [34]. Public-private partnership owes much to mutual risk-sharing [35], and also requires progressive thinking to successfully implement the PPP model [36].

It is worth noting a large number of works devoted to the difference between motivation and incentive mechanisms in the organization of work between the public and private sectors' staff $[24,29,30]$, as well as a risk assessment in the implementation of projects within the framework of PPP [36-43].

Literature analysis revealed that the development of PPP began with infrastructure industries. Then, it was implemented into almost all spheres: healthcare, construction, energy, etc. Nowadays, this instrument of interaction between the state and the private sector remains in demand, in particular, in countries with emerging economies [30-32,42,43].

It is worth noting the Russian scientists-economists who made an important contribution to the investigation of the problems of relations between the state and business: Vashlomidze, E.V.; Varnavsky, V.G.; Klimenko, A.V.; Deryabina, M.; Kholodnaya, N.D.; Kochetkova, S.A.; Moiseeva, I.V.; etc. In their research, Vashlomidze, E.V.; Kokorev, I.A. and Stolyarova, V.A. considered PPP as a set of subjects, objects and methods of interaction in the process of achieving the desired socio-economic results [44]. Varnavsky, V.G. considered the mechanisms of PPP in economic policy [45]. Deryabina, M. studied the problems of redistribution of the powers of property rights arising in the framework of PPP implementation: the author regarded certain forms of PPP as an alternative to privatization [46].

Kholodnaya, N.D. investigated the problem of the formal definition of PPP and its role in the modern economy, because the author identified the similarities and differences 
between PPP and public procurement. The researchers also paid attention to the usage specifics of the PPP mechanism in the innovation and infrastructure sectors [47]. Kochetkova, S.A. and Moiseeva, I.V. described the structural model of PPP in the strategic management of the region in their monograph [48].

However, despite the existing extensive academic literature, the analysis revealed insufficient theoretical and methodological development of the organizational and economic mechanism of public-private partnership within the framework of the oil-refining sector. Thus, the aim of this study is a critical analysis of the possibility of implementing a public-private partnership in the Russian oil-refining sector.

\section{Materials and Methods}

The study applies the method of critical analysis, adapted to the purpose, and includes four stages:

Stage One-“Preliminary analysis". At this stage, the researchers check the relevance of the chosen topic by analyzing the Russian oil-refining sector, assessing the existing supporting methods and their impact on the sector, key development trends as well as constraints.

The information base includes analytical and statistical reports of consulting agencies, the Ministry of Energy of the Russian Federation, oil-refining companies reports, and reports of the Federal State Statistical Service of Russian Federation; regulatory documents: Energy and Resource Policy till 2035; draft laws on tariffs and multilateral agreements; and refining experts' analytical articles.

The research methods include the following:

- Desk Research (gathering information) was applied in forming the information base for stage 1 .

- The data processing was carried out using theoretical methods such as analysis, including qualitative and retrospective, and synthesis.

- Hypothetical method: the authors put forward a hypothesis based on analogy (incomplete induction) [49].

Stage Two-“Evaluation". This stage is characterized by an assessment of a PPP mechanism's efficiency in the oil-refining sector. The analogy method is applied based on the foreign countries' experience of the PPP implementation [22-37,39-43,50-72] and Russian experience of multilateral agreements [38,44-49,73-88]. Active use of this tool abroad substantiates its relevance and importance in the sustainable development of the oilrefining sector. The authors used a synthesis method that allows to reasonably recommend the PPP institution in the Russian oil-refining sector to obtain the synergetic effect for the development and efficiency improvement.

The hypothesis' transformation into a recommendation is as follows: PPP is recommended for the Russian oil-refining sector to increase its investment attractiveness through compliance with the principles of sustainable development.

Stage Three - “Critical analysis of the institutional environment for the PPP mechanism implementation".

Hypothesis $=>$ Recommendation $=>$ Results and Discussion:

The drivers and barriers to effective PPP implementation have been revealed. The authors formed the following four groups of stimulating factors: (1) financial; (2) technological; (3) innovative; and (4) industry-specific. The barriers are divided into eight groups: (1) financial; (2) institutional environment; (3) risks; (4) human resources; (5) psychological; (6) tax policy (physical policy); (7) competitive mechanisms; and (8) way of doing business.

Clarification of the hypothesis-recommendation: the introduction of PPP institution in the Russian oil-refining sector is faced with several drivers, restrictions, and obstacles.

Stage Four-"Formation of conclusions".

Hypothesis $=>$ Recommendation $=>$ Results and Discussion $=>$ Conclusions: 
The institute of PPP can be introduced and effectively implemented in the Russian oil-refining sector if the barriers identified by the authors are eliminated or reduced.

All stages are carried out in compliance with logic and reasoning. The study is confirmed by an extensive number of sources.

All methods are chosen as a result of the restrictions, as well as the review concept of this article. The following fact should be noted as a restriction. The oil-refining sector is one of the strategically important sectors in Russia. It is impossible to monitor the annual reports of several companies that are part of multilateral agreements. Moreover, only general quantitative indicators appear in open sources. This is also the reason it is difficult to apply quantitative methods to data. This justifies the use of the qualitative research methods listed above.

\section{Results and Discussion}

\subsection{Oil-Refining Aspects of Russian Energy Policy}

Russia is a part of the global oil processing market and is one of the three world leaders competing with the United States, China, India, Japan, Iran, Saudi Arabia, and others (Figure 4).

\section{0}

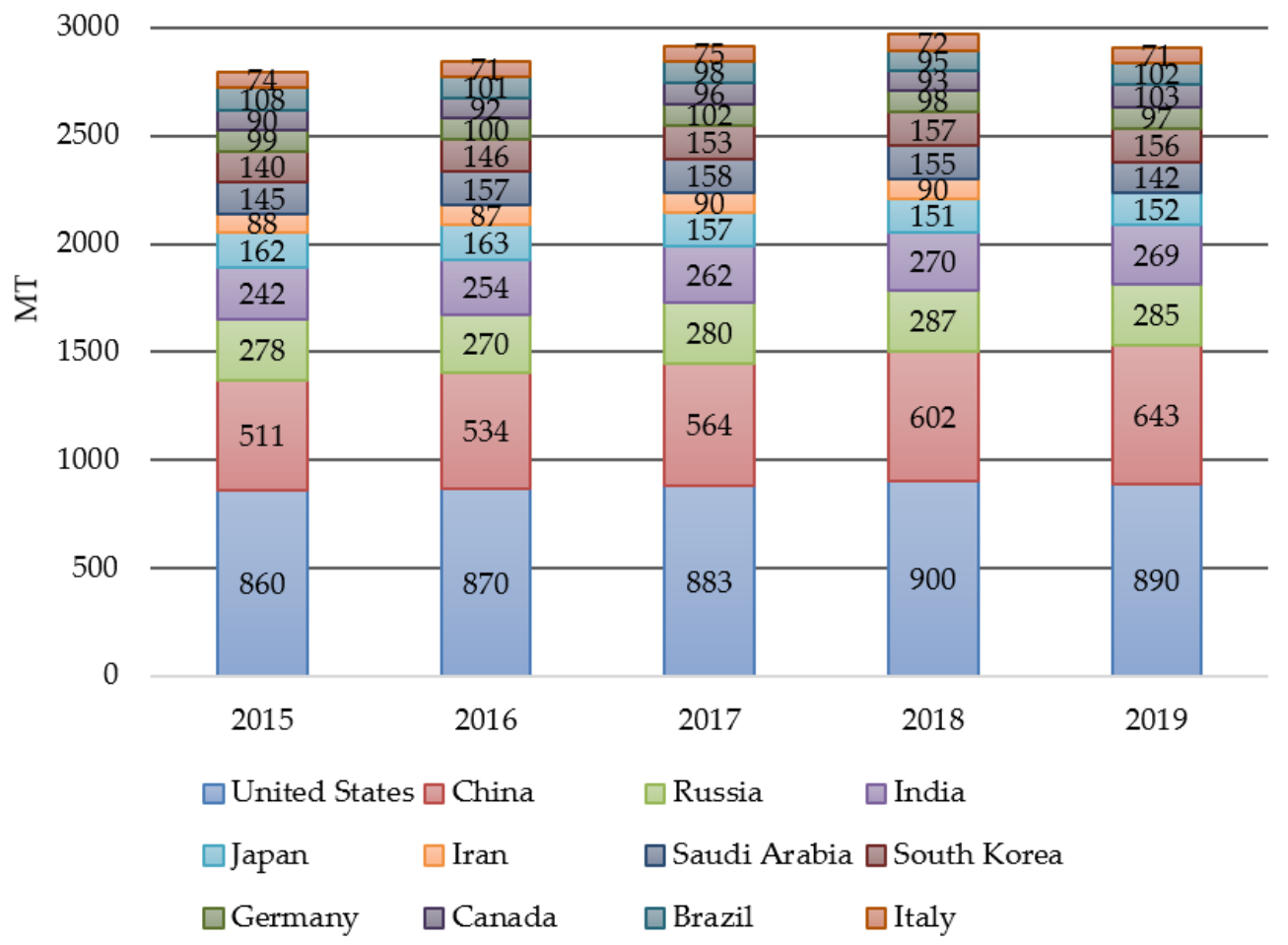

Figure 4. World leaders in oil refining production 2015-2019, million tons. Source: compiled by the authors according to [15].

In 2019, 285 million tons of oil was processed, slightly lower than the volume of primary processing of crude oil in the previous year by $0.7 \%$ or 2 million tons.

According to reports of the Russian Ministry of Energy, the oil-refining process was carried out by 37 specialized large oil refineries with refining volumes of more than one $\mathrm{Mt}$ per year, as well as mini-refineries. A percentage of $11.3 \%$ of refineries and mini-refineries are independent and $83.4 \%$ are part of vertically integrated companies (hereinafter referred to as VIC). The last $5.2 \%$ are held by three large independent refineries of the New Stream (Novyy Potok) holding company (Figure 5). 


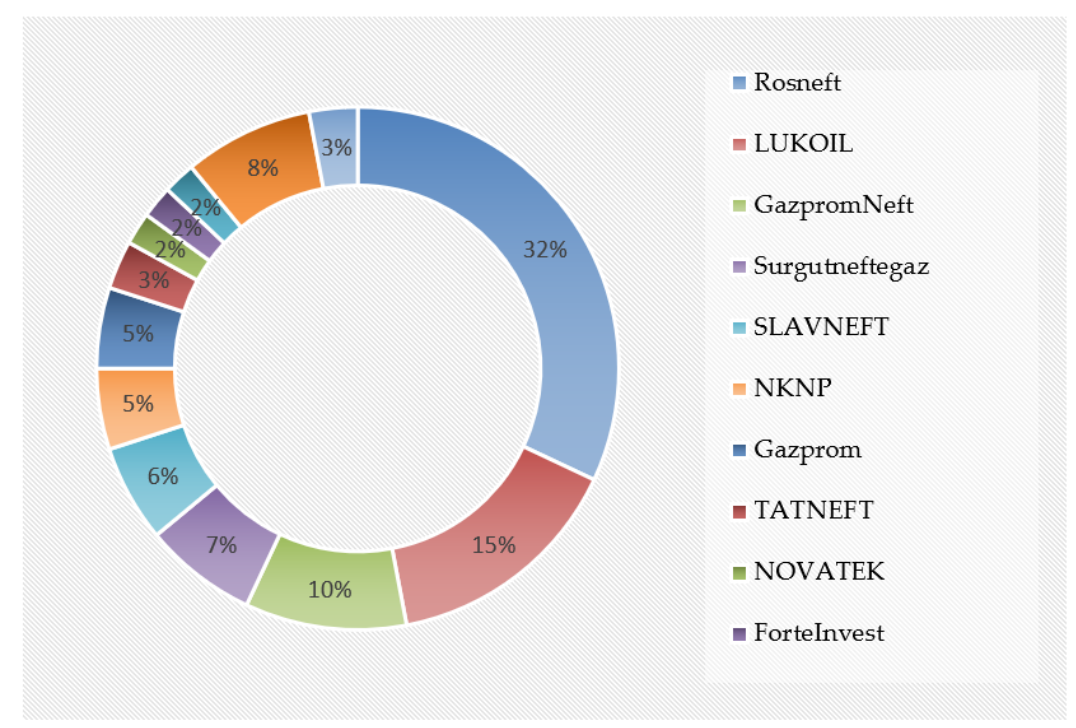

Figure 5. The market of primary oil refining in the Russian Federation. Source: [89].

In their research of the domestic oil-refining sector, which has been developing for nearly 30 years, the authors have revealed key development trends as well as inhibiting factors, associated with both the technical aspects and economic barriers [90].

The maximizing oil refinery depth should be noted as a key one according to the current trends of the oil-refining business development [91]. Domestic refineries are characterized by a relatively low oil-refining ratio (Figure 6): $82.8 \%$ (2019), compared to 95\% in the United States, and about $90 \%$ in Europe, directly affecting the low competitiveness of domestic oil products with foreign goods [92].

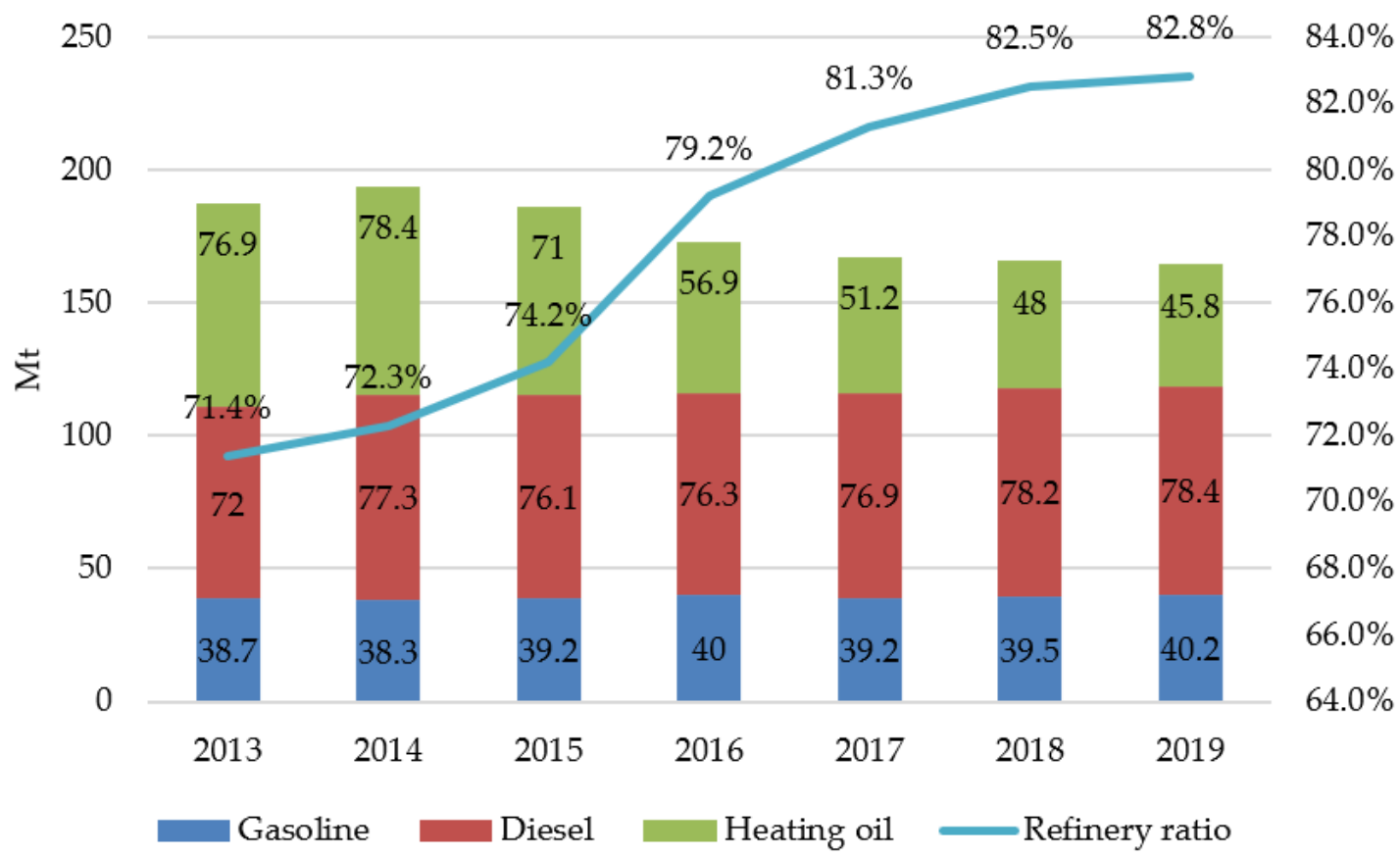

Figure 6. The production of main petroleum products in Russia, million tons. Source: compiled by the au-thors according to $[16,89]$.

It is worth noting that, in 2019, the domestic market was supplied (Figure 6):

- gasoline- $40.2 \mathrm{Mt}(+1.7 \%$ or +0.7 million tons vs. 2018$)$;

- diesel-78.4 Mt (-0.2\%, or -0.2 million tons vs. 2018), 
- $\quad$ heating oil- $45.8 \mathrm{Mt}(-4.8 \%$, or -2.2 million tons).

According to Figure 6, there was a significant decrease in heating oil production from 2015 to 2019: $-36.6 \mathrm{Mt}(-71 \%)$. This trend was due to the Tax Maneuver that came into force in 2014 as a part of the Russian Energy and Resource Policy. As we have already mentioned, the current institutional environment is not conducive to attracting large investments in the refining sector [93]. Therefore, companies reduced the volume of oil refining as a direct impact of the introduction in 2014 of the Tax Maneuver after a number of sustainable development years [94]. The Tax Maneuver is aimed at a gradual increase in fiscal payments in the sphere of natural resources (mineral extraction tax or mineral duty) with a simultaneous reduction in duties on the export of oil and gasoline abroad over six years (2019-2024). As a result, by 2024 the rate of export duties on oil and certain petroleum products should be reduced to zero, and a negative excise tax should be introduced for organizations that sell domestic fuel on the domestic market. This mechanism of the country's Energy and Resource Policy will entail changes in the pricing and production structure of oil-refining products. Given that refineries face the problem of low margins because of high logistics and production upgrade costs, this tax mechanism deprives the oil-refining sector of budgetary subsidies, which were formed as a result of differences between export duties on oil and oil products. Thus, the oil-refining investments' payback horizon has increased from 3-5 years to $10-15$ years. Over the past five years, there has been a nearly four-fold reduction in the oil-refining sector's investments-from 290 billion rubles in 2014 to 70 billion rubles in 2019, due to an increase in the tax burden on the industry $[95,96]$.

A damping mechanism came into effect in January 2019 as a part of the completion of the Tax Maneuver under the Tax Code. It allows oil companies to get partial compensation for lost profits due to the sale of oil-refining products, namely, fuel, on the domestic market [97]. The damping mechanism is applied to motor gasoline, diesel fuel, and aviation kerosene. The amount of compensation per 1 ton is determined as the difference between the price of the export alternative (Pexp) and the average producer price (Pprod), multiplied by the value of the compensation coefficient (Ccomp) (Formula 1):

$$
\text { Compensation per } 1 \text { ton }=\left(\mathrm{P}_{\exp }-\mathrm{P}_{\text {prod }}\right) \times \mathrm{C}_{\text {comp }}
$$

where Pexp is calculated and varies depending on the type of fuel (gasoline, diesel, jet fuelAppendix A); Pprod and Ccomp are established by the Tax Code of the Russian Federation (Appendix B) [98].

If the difference is positive, it must be multiplied according to the lost profit of companies resulting from price differences in the external and internal markets, which is compensated by the budget and at the same time curbs raising prices for domestic consumers. If the situation is the opposite and the difference is negative, a coefficient is also applied to it. Only this amount is paid by companies to the budget for the fact that the selling price of gasoline on the domestic market exceeds the price in foreign markets. Because of the COVID-19 pandemic, as well as after the failure of the OPEC+ deal in February 2020, oil prices collapsed. This, accordingly, led to a second alternative; as a result, the damper mechanism began to work against the oil sector, and, in particular, against the oil-refining sector [14].

Several legislative measures have been developed and partially implemented in order to support the Russian oil-refining business. Thus, a ban on the import of gasoline into the Russian Federation was introduced. There are "customs subsidies" because of the difference between a lower export duty on light oil products and a higher duty on oil $[93,97,99]$. Currently, there is a reverse excise tax, differentiated depending on the logistics and configuration of the refinery. In July 2020, a draft of the law about a 1.3 multiplier for crude oil to the reverse excise tax for some enterprises was developed. The enterprises should be ready to conclude additional agreements about the modernization of plants by 1 July 2021 , and the corresponding processing capacity of raw materials in a volume of more than 600,000 tons since 2017 [73]. 
However, despite the above supporting legislative measures, the planned effect was not obtained. For example, in 2017, due to "customs subsidies", 1 trillion 100 billion rubles were to be spent on upgrading refineries, while for the entire period from 2005 to 2017, oil companies earned 11.2 trillion rubles thanks to this mechanism, some of which was also intended for upgrading refineries. As a result, for 2005-2017 only 2.8 trillion rubles were used according to their intended purpose-to upgrade refineries $[73,100]$.

Moreover, it is necessary to note a high level of depreciation of fixed assets, which physical indicator is about $70 \%$ as a critical technological issue typical for the domestic oilrefining industry. This problem leads to an increase in the energy intensity of production, and a decrease in efficiency [74]. As a result, operational and capital costs (OPEX, CAPEX) increase. The current situation contradicts the generally recognized world standards for any business development: increasing efficiency while reducing costs. It is evident that the production of high-quality petroleum products that meet international technological standards and can compete on a par with foreign products necessitates the construction of new production facilities and upgrading existing ones [101]. This, in turn, also entails large-scale investments.

To summarize: with the oil-refining industry being constrained by the above factors, as well as the need to achieve the principles of sustainable development, there is a need to modernize existing refineries. It can be done by increasing the oil refinery depth, improving environmental sustainability, and diversifying production depending on demand and territorial location. It is also important to resolve the issue of high transport costs for oil products due to the distance of the refinery from major consumers. All of these factors require huge investments and support from the state. Effective dialogue between the government and the private sector can be achieved using a public-private partnership, implying effective cooperation between the state and private business [102]. This tool is considered an effective one in the implementation of the Russian Energy and Resource Policy, which is reflected in the main document-Energy Strategy of Russia for the Period till 2035 [103].

Hypothesis 1: To achieve sustainable development, to increase the investment attractiveness of the oil-refining sector, as well as implementation of the Energy and Resource Policy till 2035, the public-private partnership introduction is considered.

\subsection{Public-Private Partnership in the Russian Oil-Refining Sector: Synergetic Effect and Sustainable Development}

Literature analysis revealed that there were controversial points about the effectiveness and transparency of the PPP implementation as a tool that contributes to sustainable business development. First of all, the classic forms of PPPs (concessions and leases contracts) are criticized, that subsequently leads to privatization $[24,29,50]$. In addition, this instrument is indirectly seen to circumvent fiscal constraints. A few researchers justify the popularization of PPPs in the energy and water sectors in the 1990s by a combination of these circumstances [26,51,52]. Construction and service companies also find PPPs an attractive tool $[30,32]$. So, one PPP contract can provide them cash flow for a long period of time. Companies, in turn, lobby the politicians' interests to initiate the creation of PPP. This factor may also have a negative impact on the competitive component of the market, as well as on the level of service. It is worth noting that since the very inception of PPP has been criticized for the high cost of attracting financial resources: this tool is more expensive than the use of public funding. Why? The process of "sharing or transferring risk" within PPPs plays a significant role and is not free $[53,54]$. Thus, it is possible that the government overestimates the risk and overcompensates the private sector for its acceptance. This leads to higher costs of PPPs than direct public investment [32]. Another argument against this institution is the following statement: PPPs can be used to conceal government borrowing while providing long-term government guarantees of profits for private companies $[22,50]$.

From our point of view, it is necessary to consider the positive or negative impact of the mechanism according to a specific sector for each country. There is only one restriction 
in our article-the Russian oil-refining sector. All research results are considered to it. Thus, we identified the following factors as positive effects of the PPPs implementation, justified by literature review and applicable to the oil-refining sector [55]:

- $\quad$ state guarantee $[37,56]$;

- $\quad$ beneficial economic conditions [33,57];

- $\quad$ effective risk sharing [25,33,57];

- $\quad$ project feasibility [37,56];

- $\quad$ sound economic policies [33,37];

- good governance [58].

Nowadays, private agreements are currently one of the most effective tools for state regulation of affairs in economic areas according to analysis of domestic research $[44,45,47,75,76]$. The implementation of the PPP mechanism will allow the usage of the state regulatory functions and the available resources of domestic companies [77] to solve several sustainable development issues [78] and to achieve a synergetic effect (Figure 7).

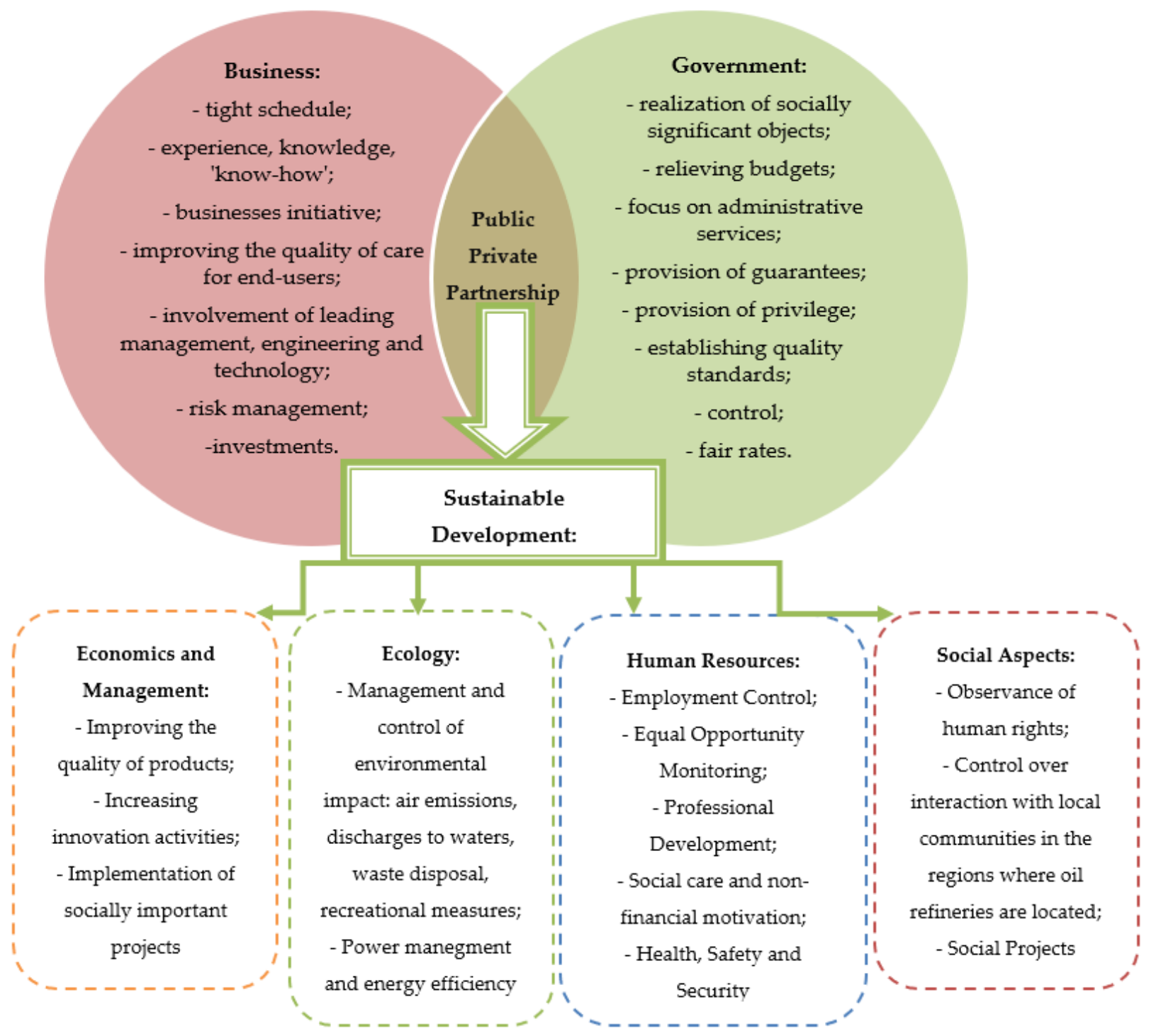

Figure 7. Public-private partnership: synergetic effect and sustainable development. Source: compiled by the authors.

Moreover, PPP is considered as one of the key tools of sustainable development by the world community [104]. This also meets the requirements of the Forecast of the longterm socio-economic development of the Russian Federation for the period up to 2030, 
that excludes the possibility of further oil-refining sector economically efficient functioning outside the concept of sustainable development [105].

The opportunity to improve business efficiency is the key argument supporting the use of PPP as a tool for the oil-refining sector's sustainable development in the Russian Federation [52,59]. For example, Mollisi proves that firms operating in the Italian energy sector under PPP have increased their productivity by $14 \%$ [60]. Researchers associate this in part to the internalization of spillover positive externalities arising from the longterm nature of PPP contracts between the different stages of a project. Furthermore, such long-term contracts can stimulate the use of innovative solutions throughout the process, in which private know-how and previous experience in the sector are considered extremely important [61]. These effects are important in the discussion of the principles of sustainable development, as well as the possible economic effect of implementing PPPs in the oil-refining sector. This tool can also serve as an additional source of financial resources, allowing the government to save on scarcity and expensive government funding [21,25].

PPPs improve the quality of business. Thus, projects created under PPPs contribute to an upgrading of quality as a result of increasing competition on the market and the desire to meet the standards set by PPP projects [31,62].

Partially, this mechanism has been tested in the form of quadripartite agreements in the domestic oil-refining sector since 2011 among the Federal Antimonopoly Service (FAS) of Russia, the Federal Service for Environmental, Industrial and Nuclear Supervision Service (Rostekhnadzor, Moscow, Russia), the Federal Agency for Technical Regulation and Metrology (Rosstandart, Moscow, Russia), and 12 oil companies [79-83].

The point of funding is another controversial point in the implementation of PPPs in the industry. A number of researchers argue that PPPs are not a new source of funding, but only affect the temporary distribution of public revenues and expenditures, since, ultimately, the funding will fall on the users and taxpayers [53]. This statement does not reflect the real situation in the Russian oil-refining sector. It is worth noting that the PPP implementation using all government resources including investments never happened. Moreover, the participation of state structures is limited to control in most cases (Table 1).

Table 1. Controlling functions in frame of quadripartite agreements.

\begin{tabular}{ccc}
\hline Federal Antimonopoly Service & $\begin{array}{c}\text { Federal Service for Environmental, } \\
\text { Industrial and Nuclear } \\
\text { Supervision Service }\end{array}$ & $\begin{array}{c}\text { Federal Agency for Technical } \\
\text { Regulation and Metrology }\end{array}$ \\
\hline $\begin{array}{c}\text { Compliance by oil companies with } \\
\text { obligations in terms of the volumes } \\
\text { actually produced by oil companies of } \\
\text { oil products. }\end{array}$ & $\begin{array}{c}\text { Implementation of investment programs } \\
\text { aimed at modernizing oil-refining } \\
\text { capacities, providing for a phased } \\
\text { transition to the production of higher } \\
\text { quality types of oil products. }\end{array}$ & $\begin{array}{c}\text { Compliance by oil companies with } \\
\text { obligations regarding the compliance of } \\
\text { oil products produced by oil companies } \\
\text { with the requirements of } \\
\text { technical regulations. }\end{array}$ \\
\hline
\end{tabular}

Source: compiled by the authors based on [82].

There are many problems such as the multiplicity of persons who duplicates their functions, the duration of procedures, etc. (these will be thoroughly discussed in Section 4.3.2).

However, a positive trend in the yield of light petroleum products is obvious: an increase from $55.7 \%$ (2011) to $62.1 \%$ (2019) in the overall refining structure since that moment [80]. Thus, the previously identified discrepancy in the spending of targeted funds generated by oil companies as a result of the "customs subsidy" is impossible within the framework of quadripartite agreements. This is because three bodies control the implementation of the agreements' conditions, ensuring a sustainable supply of petroleum products on the Russian market in accordance with the emerging level of demand, together with the provisions of the Technical Regulations concerning the release of motor gasoline and diesel fuel into circulation are also under control and regulation. Moreover, 2 trillion rubles were invested in the construction and modernization of refineries during the period of implementation of the existing quadripartite agreements. It made it possible to increase the 
volume of recycling with additional social, economic, and environmental effects (Figure 7). It is worth noting that the obligations under the agreements also led to the planned modernization of the existing refineries, directly affecting the oil-refining ratio [73]. The oil-refining ratio is currently expected to reach $91 \%$ with an output of light oil products of $79 \%$ within the framework of the agreements [83].

The authors identified drivers and barriers to the PPP mechanism's implementation that should be taken into account.

\subsection{Public-Private Partnership in the Russian Oil-Refining Sector: Drivers and Barriers}

\subsubsection{Drivers}

The main stimulating and constraining factors of multilateral PPP agreements in the domestic oil-refining industry were studied.

The financial, technological, and innovative factors, as well as consideration of negative trends in the industry that can be reversed using the PPP mechanism, can be identified as stimulating factors that have a positive impact on the activities of all participants in multilateral public-private agreements (Figure 8).

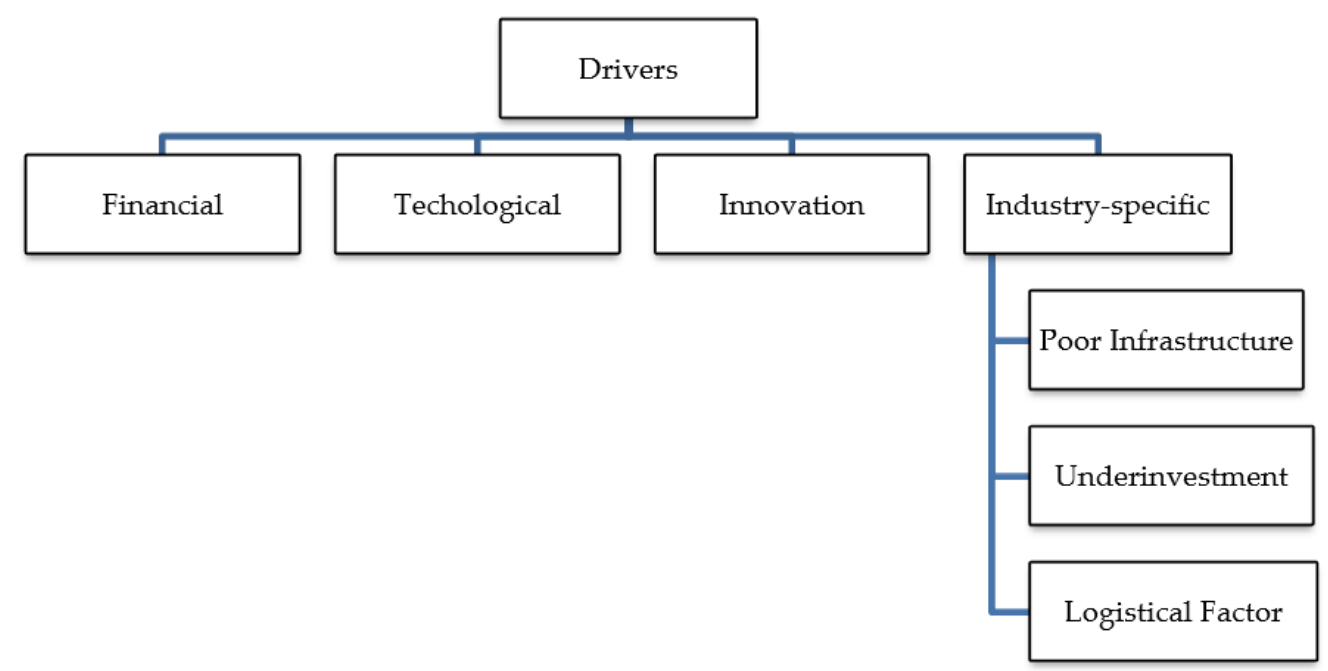

Figure 8. PPP in the oil-refining sector: Drivers-Russian case. Source: compiled by the authors.

Increasing return on invested capital and guaranteed return on invested capital are the main changes in terms of improving the financial component's efficiency in the oil-refining sector sustainable development $[56,63,64]$.

Due to the high level of both physical and moral depreciation of fixed assets, the technological factor is currently does not meet modern requirements. This, in turn, increases the negative effect on the social-ecological area and reduces the competitiveness of the final products.

Firstly, innovative development as a positive external effect of the introduction of PPP was considered earlier [61]. Secondly, the innovation factor was considered with the duality characteristic of Russia in this section. On the one hand, the already existing shortage of the main components of innovation infrastructure as a result of the lack of the integrated system of interaction between science and the private sector (business) allows us to consider this factor as a stimulating factor in terms of reviewing development priorities and identifying competitive advantages. Thus, at present, management's interests are focused on the development of portfolio management, performance management programs, and strategy implementation control, as well as methods of reducing costs to increase competitive advantages. In turn, the identified shift in priorities leads to low ecological indicators as well as low demand and low level of an innovative component in the oil-refining sector. On the other hand, because of the current global situation in the oil market, with foreign 
companies' tough competition, inter-fuel competition is pushing further the innovative business component development.

The fourth "industry-specific" group of factors is the most controversial. However, we suggested the previously listed problems of the oil-refining industry (lack of investment, territorial remoteness of production and sales markets, and the need to develop infrastructure) that serve as key drivers for the PPP institution development.

\subsubsection{Barriers}

The noted potential of the PPP mechanism for the introduction and spreading is faced with several constraining factors in our country. We identified and classified the factors into the following eight groups (Figure 9).

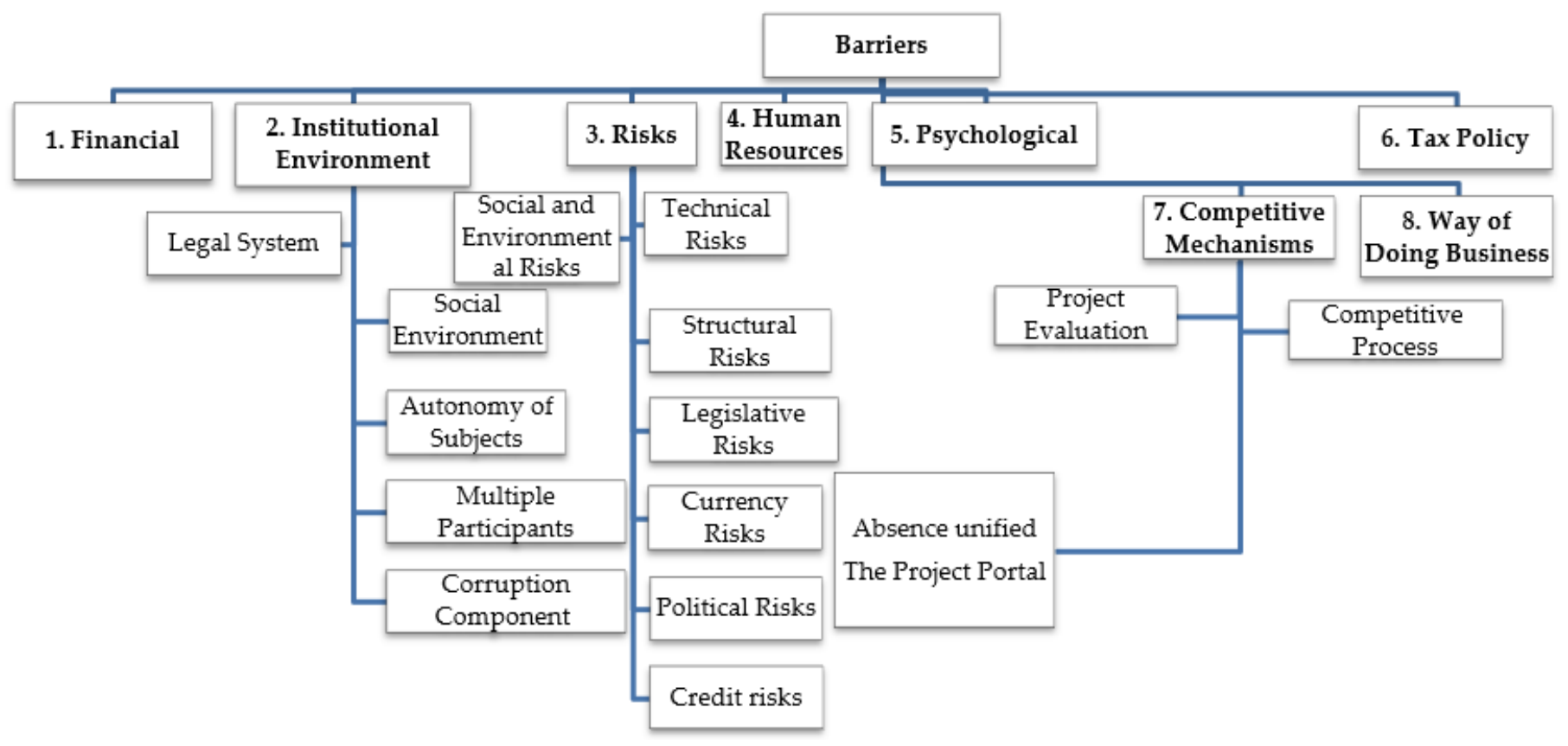

Figure 9. PPP in the oil-refining sector: constraints. Source: compiled by the authors.

1. Financial factor. Despite the large number of financial instruments used abroad for investment projects $[28,33]$, our country has not yet formed a final understanding of the holistic mechanisms of projects' financing. Possible funding sources include budgets of various levels, credit resources, foreign and domestic investors' resources, funds of international financial organizations. It is also worth noting the likelihood of inaccurate calculation of construction costs (cost overrun) $[65,66]$ or incorrect calculation of net present value.

2. Institutional environment:

- Currently, one of the most pressing problems is the development of national legislation to regulate PPPs, in particular regarding difficulties in the distribution of new rights and powers by different administrative levels $[46,48]$.

- Duration of time scarcity factor. The process of developing and passing a draft law takes a lot of time. Thus, the development and consideration of the law "On Concession Agreements" lasted 12 years: from 1993 to 2005; and the Federal Law on PPP, five years from 2011 to 2015.

- Broad autonomy of Federal subjects and local authorities. Since PPP projects involve ensuring the competence of the state, regions, and local authorities, this factor complicates the legal and institutional regime. It is worth considering that each administrative level also has a separate regulatory and legal framework, which makes it difficult to cooperate in a large PPP project that affects several 
regions. Thus, the key institutional problem of PPP implementation is the need to take into account the interests, legal norms, and positions of the center and regions of the country.

- The imperfection of existing legislation. Many laws lack a mechanism for dividing most of the possible risks between private and state capital, or unfavorable conditions for participation are established for the business, which can be expressed, for example, as high penalty points with the investor; short terms of project implementation [106]. A particular case of the imperfection of the regulatory framework is the absence of the concept of state property management, which ensures regulation of the following key issues [51,52,67]:

- What should remain in state property?

- What can be privatized?

- What could be transferred to the business for management/ownership/use (under certain conditions)?

- The attitude of society, government, and business to the PPP mechanism. Thus, all participants in the process have an incomplete and distorted understanding of the PPP mechanism, its application, and possible socio-economic short, medium and long-term effects [35,36].

- Lack of an integrated approach. The development of the PPP problem is not carried out systematically in the country: lack of regularity, lack of due attention to economic and social problems, lack of a unified methodology, as well as a mechanism for the functioning and regulation of this instrument.

- The plurality of parties in the PPP agreement. A separate issue of multilateral agreements is the complexity of their coordination and responsibility distribution between the parties. As a solution, the creation of a special purpose vehicle company (SPV) is considered. It levels the multiplicity of persons in the contract as follows: the SPV Company is one of the parties to the agreement and is responsible for the implementation of the project as a whole and at the same time has the right to conclude contracts with various companies to implement certain aspects of the project [84].

- Lack of a clear procedure for the implementation of PPP agreements. To date, there are no effective mechanisms for the formation of a clear and transparent procedure for the implementation of projects within the PPP framework, which leads to a decrease in the interest of investors. It is necessary to create and implement a tool that would allow the implementation of projects with the maximum level of transparency and preservation of all the terms of the agreements, including legislative ones. As we have already mentioned, long-term projects within the framework of PPP are an opportunity to receive a state-supported funding during all project's period. This circumstance creates huge incentives for corruption and opportunistic behavior [107]. Precedents have been identified in a number of countries, and also apply to our country in full measure [68-71,108].

3. Risks:

A. Structural risks specific to the oil-refining sector: the presence of market risk associated with fluctuations in the revenue stream.

B. Foreign exchange risk is the main obstacle for foreign investors.

C. Political risks. These risks are poorly predictable and have a significant impact on the feasibility and successful completion of a PPP project. The sanctions applied by various countries are unpredictable and have negative consequences, including a decrease in investment attractiveness for foreign partners.

D. Credit risk and loan collateral. Often, oil refineries use borrowed funds to develop production, which leads to an increase in the level of dependence on the situation in the oil market, including on the volume of raw materials, their cost, demand for raw materials and final products. Refineries are equipped 
with hardware of a certain type that allow processing oil of specific grades with certain characteristics. In case of disruptions in the supply of raw materials to the refineries for reasons related to the development of fields, oil refineries sharply lose in income, and the level of profitability decreases, which, in turn, leads to a decrease in the main indicators characterizing financial stability and solvency. With a decrease in the above indicators, enterprises lose their investment attractiveness for creditors.

E. Social and environmental risks. Within the framework of this classification, it is necessary to consider the negative impact of the facility, erected as a result of a PPP project, on the environment, as well as the level of technical safety of the facility and its impact on the health of people living in the areas adjacent to the facility [106].

F. Legal risks. In Russia, amendments are regularly made to the documents regulating the activities of enterprises in various fields. The instability of the existing legal system can lead to contradictions between the parties of a civil law character. At the same time, in some cases, appeal to the courts does not return the desired result. Companies are poorly protected from disputes with government officials, and the volatility of the Russian legal framework leads to a significant increase in risks.

G. Technical and technological risks. Problems in the application of new technology in the development of a field or construction of an oil refinery, problems in the field of design, including design of construction, can lead to irreversible consequences. The consequences can be purely economic in nature, but environmental or social problems can also arise. It is necessary to introduce a risk assessment at the initial design stages in the oil and gas industry in general, and in the design of refineries in particular [38].

4. Human Resources. Lack of qualified personnel with experience in managing PPP projects. The total number of specialists in the area of public administration capable of assessing the advantages and disadvantages of various forms of a public-private partnership at a high professional level is catastrophically limited. Despite the presence of disciplines in specialized universities that allow studying the principles of the PPP mechanism, there is a lack of graduates who can carry out the high-quality implementation of PPP, and considerable professional experience is required [18].

5. Psychological factor. This refers to the unwillingness of Russian society to transfer to the private sector the functions of owning and using social facilities that are state and municipal property.

6. Tax (fiscal) policy. Regular changes in Russian legislation lead to increased risks in the implementation of PPP-based projects, as well as a decrease in their investment attractiveness.

7. Competitive mechanisms in Russian reality, as a rule, have certain drawbacks, but the main issues are:

A. Assessment of the commercial efficiency of PPP projects. When assessing, there are controversial issues regarding the need to account for the scale of projects, the availability of resources, risk distribution, cost and quality ratio [64] as well as the feasibility of conducting a legal, technical and financial assessment of PPP projects [72]. Russian researchers (O.G. Timchuk, E.I. Gabdullina) consider it necessary to assess the economic and socio-economic effects of the implementation of PPP projects [85].

B. Tender procedure entails difficulties in terms of preparation and consideration of applications, this is a rather lengthy procedure, which can have several stages. Given the limited number of companies applying for the tender, the latter may not take place, which also leads to a delay in project implementation.

C. Absence of a unified Internet portal for projects. Despite the existence of the “Unified Information System for Public-Private Partnership in the Russian 
Federation" created by the Center for the Development of Public-Private Partnership, it has several disadvantages: not all PPP projects are displayed there; incomplete information is provided. Business often finds out the project after the tender.

8. Way of doing business. It is worth mentioning separately the participation of foreign partners and the emerging constraints. Ernst \& Young has published a study that describes some features of the style of doing business by Russian partners that negatively affect the level of trust on the end of foreign investors. These features include: focus on short-term results, the complexity of the internal process of agreeing on decisions (lack of internal coordination), and inconsistency and lack of transparency in the decision-making process [86].

Thus, at present in Russia, there are several restraints and obstacles on the way to the establishment of the public-private partnership institution.

\section{Conclusions}

The operating conditions of the global refining industry are changing. Price shocks on the world oil market because of COVID-19 and OPEC+ are tightening requirements to petroleum products, falling demand for heavy fuels that limits extensive development of refining and brings to the forefront deep conversion of hydrocarbon raw materials through secondary refining processes. This trend and the importance of recycling are also noted in the annual OPEC World Oil Outlook 2020 Report [87]. Russia must meet the global challenges, which means reducing the production of fuel oil and dark petroleum products. This also meets the Russian Energy and Resource Policy till 2035. Technological equipment becomes a key factor of global competitiveness in the industry. The focus is on modernization and technological re-equipment, in particular, the introduction of modern conversion and hydro-refining units contributes to improving the depth of oil refining.

However, support for hydrocarbon processing is provided by the system of state subsidies through the mechanism of customs duties on oil and petroleum products. The system supports refiners if oil prices are high. When prices fell, the volume of customs subsidies rapidly decreased, and the damper on petroleum products worked in the opposite direction. Thus, today oil-refining companies pay extra money to the state budget for the petroleum products supply to the Russian market, while maintaining the previous fuel prices. All the above confirms the failure of the existing tools of the oil-refining sector's supporting mechanism. Moreover, the sector is experiencing a shortage of medium- and long-term investments.

These factors substantiate the necessity of the state support for the oil-refining sector within the framework of the public-private partnership implementation, taking into account the positive experience of PPP projects in foreign countries. This mechanism should increase the depth of oil refining and the yield of light products, as well as improve the environmental characteristics of motor fuels, which in turn will affect the competitiveness of our industries: the export commodity should be not only crude oil but also products of higher redistribution. However, these agreements led to positive results. Despite the discrepancy between the planned and actual level, an increase in both the depth of processing and the yield of light oil products still took place, although not in full (discussed in Section 4.2). That confirms the efficiency of the mechanism.

However, the findings indicate the ambiguity of the mechanism's implementation in the modern realities of the Russian oil-refining sector. This is confirmed by the failure of oil-refining companies to fulfill their obligations on all the key points of the agreements on modernization. Thus, under the initial conditions, the level of oil refining depth was supposed to be $87 \%$ (2015), while the actual level in 2019 was $82.8 \%$ (Figure 10). 


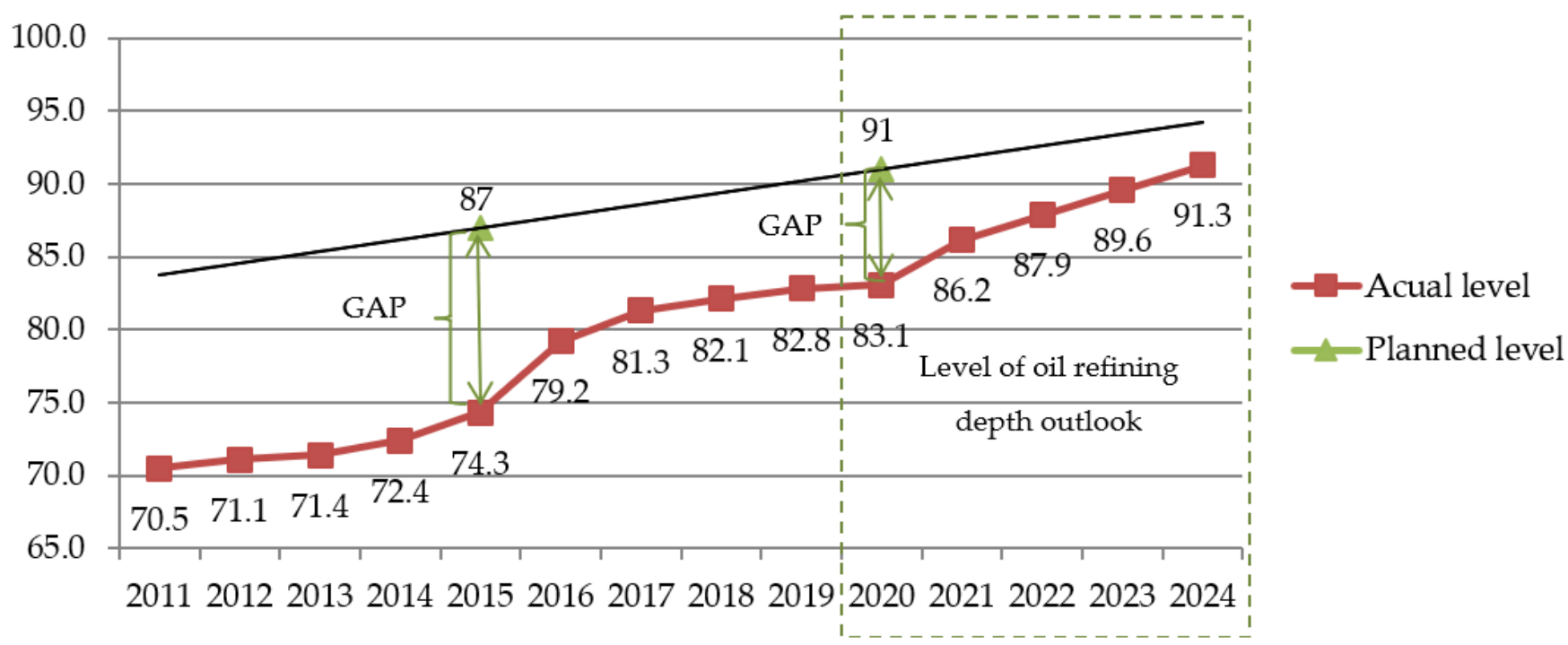

Figure 10. Level of oil refining depth, \%: 2011-2020—actual level; 2021-2024—outlook. Source: compiled by the authors.

We analyzed the depth of oil refining level in the period from 2011 to 2019, as part of the study. Figure 10 shows the gap between the actual and planned indicators. Level of oil refining depth outlook was carried out using extrapolation method, which identified the year when the actual level of oil refining depth will reach the planned level-2024. Moreover, this indicator should reach the level of $91 \%$ in 2020, according to the forecast of long-term socio-economic development of the Russian Federation for the period up to 2030 [59], which also does not correspond to reality. It confirms the ineffectiveness of the PPP mechanism due to the identified barriers.

It was also planned to put 134 units of secondary oil refining into operation by 2015 . In actuality, 86 units were put into operation by the end of 2020: $36 \%$ behind the plan.

The level of the yield of light oil products was planned to increase to $79 \%$ by 2015 , which is 17\% less than the actual figure in 2020 (Figure 11). There are outliers in Figure 11. They occurred in 2014, which is justified by the economic sanctions against Russia as a result of political actions in the international arena. There is a noticeable decrease in the rate of indicator growth due to the above-mentioned reasons (COVID-19, OPEC+) in 2020. The inconsistency of the fact to the plan will continue until 2036. Moreover, this indicator should reach $91 \%$ by 2030 [104], which, according to the outlook, will not be possible.

It is worth to note that the terms of the refinery modernization agreements within the framework of the four-party agreements have been constantly postponed: from 2015 to 2020, then to 2022, and now to 2024 [82]. A number of oil-refining companies have pushed back the deadline to 2027 [88].

We suppose that lags in the key indicators of the oil-refining industry modernization are partly due to the identified and systematized barriers in this paper. They prevent the effective functioning of the PPP mechanism. If they persist and there are no appropriate measures to eliminate the negative impact, PPP will continue to demonstrate its failure in the oil-refining sector.

To conclude, the authors propose to consider PPP as a tool that encourages attracting large-scale investments in the country's oil-refining sector, taking into account the abovementioned synergetic effects of cooperation between the state and business, leading to sustainable development and drivers, and stimulating its implementation. However, a positive effect from the use of the above instrument can be achieved by minimizing or neutralizing the identified barriers to the PPP mechanism implementation.

Further research on this issue will be aimed at finding a solution to the problem of leveling the barriers described in this article. 


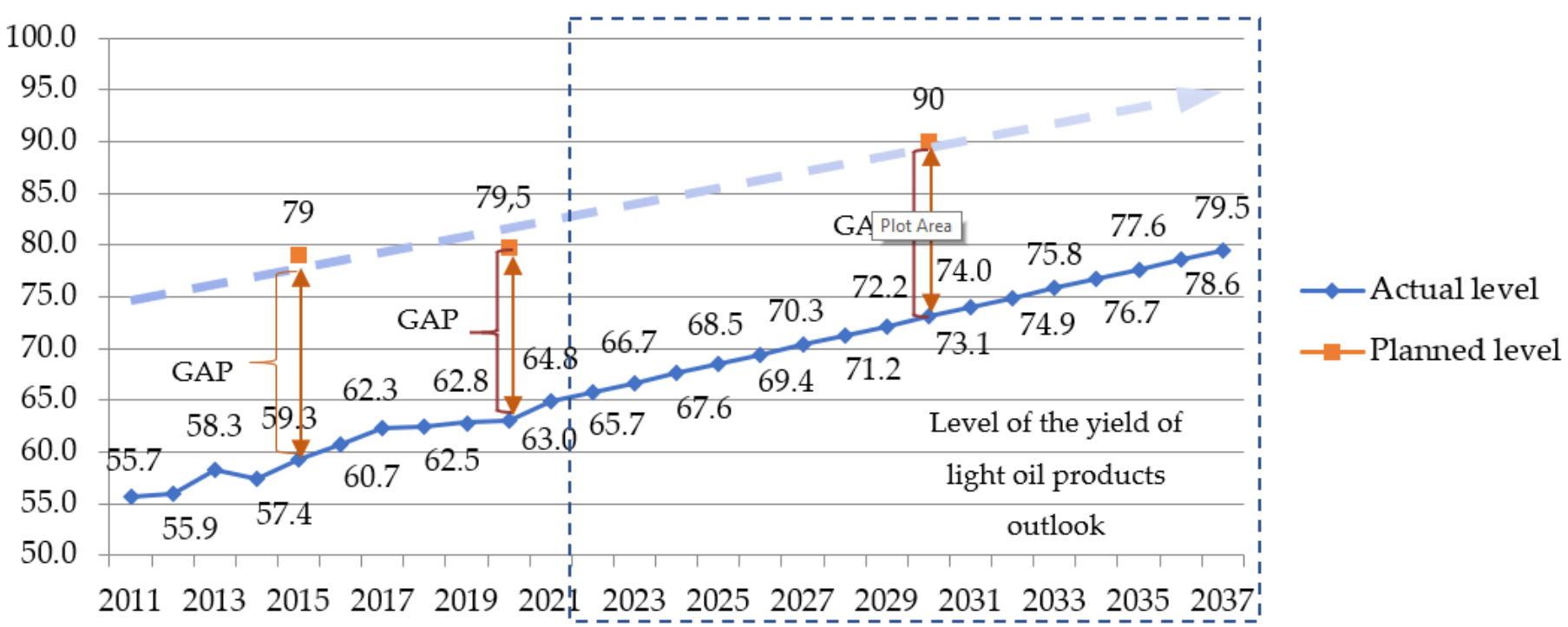

Figure 11. Level of the yield of light oil products, \%: 2011-2020—actual level; 2021-2037—outlook. Source: compiled by the authors.

Author Contributions: Conceptualization, I.F., L.N., D.Z., I.I.; methodology, I.F., L.N.; data collection, D.Z.; data analysis, I.F.; writing-original draft preparation, I.F., D.Z.; writing-review and editing, I.F., L.N., I.I., D.Z.; visualization, I.F., D.Z.; project administration, L.N., I.I. All authors have read and agreed to the published version of the manuscript.

Funding: This research received no external funding.

Institutional Review Board Statement: Not applicable.

Informed Consent Statement: Not applicable.

Data Availability Statement: Not applicable.

Conflicts of Interest: The authors declare no conflict of interest.

\section{Appendix A}

Calculation Pexp for gasoline and diesel (Equation (A1)):

$$
\mathrm{P}_{\exp }=\left(\left(\mathrm{P}_{\mathrm{aver}}-\mathrm{F}_{\mathrm{aver}}-\text { Export duty }\right) \times \text { Exchange Rate }+ \text { Excise rate }\right) \times(1+\mathrm{VAT}),
$$

where $\mathrm{P}_{\text {aver }}$-average price on the Rotterdam crude oil market (USD per 1 ton); $\mathrm{F}_{\text {aver }}$-average freight costs including transportation by sea and transshipment in ports of 1 ton from the Russian Federation seaports located in the Northwestern Federal District to the Rotterdam crude oil market (USD per 1 ton); Export duty—export duty rate (USD per 1 ton); Exchange Rate-average exchange rate of the US dollar to the Russian Federation ruble (USD/Ruble).

Calculation $\mathrm{P}_{\exp }$ for jet fuel (Equation (A2)):

$$
\mathrm{P}_{\mathrm{exp}}=\left(\left(\mathrm{P}_{\text {aver }}-\mathrm{T}_{\text {aver }}-\text { Export duty }\right) \times \text { Rates }\right) \times(1+\mathrm{VAT}),
$$

The excise tax rate is excluded from the calculation. 


\section{Appendix B}

Table A1. Producer price and compensation coefficient.

\begin{tabular}{ccc}
\hline & P $_{\text {prod }}$ & C $_{\text {comp }}$ \\
\hline & Gasoline & \\
\hline January-June 2019 & 56,000 & 0.6 \\
July-December 2019 & 51,000 & 0.75 \\
2020 & 53,600 & 0.68 \\
2021 & 56,300 & 0.68 \\
2022 & 59,000 & 0.68 \\
2023 & 62,000 & 0.68 \\
2024 & 65,000 & 0.68 \\
\hline & Diesel & \\
\hline January-June 2019 & 50,000 & 0.6 \\
July-December 2019 & 46,000 & 0.7 \\
2020 & 48,300 & 0.65 \\
2022 & 50,700 & 0.65 \\
2023 & 53,250 & 0.65 \\
2024 & 56,000 & 0.65 \\
& 58,700 & 0.65 \\
\hline July-December 2019 & Jet Fuel & \\
2020 & 48,300 & 0.6 \\
2021 & 50,700 & 0.7 \\
2022 & 53,250 & 0.65 \\
2023 & 55,900 & 0.65 \\
& 58,700 & 0.65 \\
& 61,600 & 0.65 \\
\hline
\end{tabular}

Source: [98].

\section{References}

1. Climate Action, Environment, Resource Efficiency and Raw Materials. Horizon 2020-Work Program 2018-2020. European Commission Decision C (2020) 6320 of 17 September 2020. Available online: https:/ / ec.europa.eu/research/participants/data/ ref/h2020/wp/2018-2020/main/h2020-wp1820-climate_en.pdf (accessed on 10 December 2020).

2. Masson-Delmotte, V.; Zhai, P.; Pörtner, H.O.; Roberts, D.; Skea, J.; Shukla, P.R.; Pirani, A.; Moufouma-Okia, W.; Péan, C.; Pidcock, R.; et al. Global warming of $1.5^{\circ} \mathrm{C}$. In An IPCC Special Report on the Impacts of Global Warming of Globle Warming; IPCC: Geneva, Switzerland, 2018.

3. Litvinenko, V. The Role of Hydrocarbons in the Global Energy Agenda: The Focus on Liquefied Natural Gas. Resources 2020, 9, 59. [CrossRef]

4. Stroykov, G.; Cherepovitsyn, A.Y.; Iamshchikova, E.A. Powering Multiple Gas Condensate Wells in Russia's Arctic: Power Supply Systems Based on Renewable Energy Sources. Resources 2020, 9, 130. [CrossRef]

5. Cherepovitsyn, A.; Fedoseev, S.; Tcvetkov, P.; Sidorova, K.; Kraslawski, A. Potential of Russian Regions to Implement $\mathrm{CO}_{2}-$ Enhanced Oil Recovery. Energies 2018, 11, 1528. [CrossRef]

6. Makhova, L. Effective investment policy as a factor of successful economic development. Acad. Account. Financ. Stud. J. 2018, 22, $1-9$.

7. Litvinenko, V.S.; Sergeev, I.B. Innovations as a Factor in the Development of the Natural Resources Sector. Stud. Russ. Econ. Dev. 2019, 30, 637-645. [CrossRef]

8. U.S. Energy Information Administration. Available online: https:/ /www.eia.gov (accessed on 17 November 2020).

9. The Knoema Data Workflow. Available online: https:// knoema.ru (accessed on 18 November 2020).

10. Finanz.ru. Available online: https:/ / www.finanz.ru (accessed on 18 November 2020).

11. Shvab, K. The Fourth Industrial Revolution. Moscow. 2016. Available online: https://www.vedomosti.ru/economics/articles/20 20/01/14/820569-davosskii-forum-manifest-biznesa (accessed on 12 June 2020).

12. Ria News. Available online: https: / / ria.ru (accessed on 18 November 2020).

13. A Cunning Scheme: Why Gasoline in Russia Does Not Fall in Price Even with Oil Prices as in the 2000s. Forbes. Available online: https: / / www.forbes.ru/biznes /399945-hitraya-shema-pochemu-benzin-v-rossii-ne-desheveet-dazhe-pri-cenah-naneft-kak-v-2000 (accessed on 10 August 2020). 
14. Powell, B.J.; Wittels, J. Lost in Oil Rally: \$2 Trillion-a-Year Refining Industry Pain. Bloomberg. Markets. Available online: https://www.bloomberg.com/news/articles/2020-07-05/lost-in-oil-s-rally-2-trillion-a-year-refining-industry-crisis (accessed on 5 August 2020).

15. Statistical Yearbook of World Energy.2020. Available online: https:/ / yearbook.enerdata.ru (accessed on 30 November 2020).

16. Filimonova, I.; Provornaya, I.; Nemov, V.; Dzyuba, Y. Russian Oil Refining at the Present Stage of Development. Oil Gas Vert. 2020, 17, 8-20. Available online: http:/ /www.ngv.ru/magazines/ (accessed on 5 August 2020).

17. Ke, Y.; Wang, S.; Chan, A.P.C.; Cheung, E. Research Trend of Public-Private Partnership in Construction Journals. J. Constr. Eng. Manag. 2009, 135, 1076-1086. [CrossRef]

18. Yi, W.; Chan, A.P.C. Critical Review of Labor Productivity Research in Construction Journals. J. Manag. Eng. 2014, 30, 214-225. [CrossRef]

19. Tang, L.; Shen, Q.; Cheng, E.W. A review of studies on Public-Private Partnership projects in the construction industry. Int. J. Proj. Manag. 2010, 28, 683-694. [CrossRef]

20. Wang, H.; Xiong, W.; Wu, G.; Zhu, D. Public-private partnership in Public Administration discipline: A literature review. Public Manag. Rev. 2018, 20, 293-316. [CrossRef]

21. World Bank. The U.K. Treasury Infrastructure Finance Unit: Supporting PPP Financing during the Global Liquidity Crisis; World Bank: Washington, DC, USA, 2010.

22. Brodie, M.J. Public/private joint ventures: The government as partner-bane or benefit? Real Estate Issues 1995, $20,33-39$.

23. Sarmento, J.M. Do Public-Private Partnerships Create Value for Money for the Public Sector? The Portuguese Experience. OECD J. Budg. 2010, 10, 1-27. [CrossRef]

24. Hall, J. Private Opportunity, Public Benefit? Fisc. Stud. 1998, 19, 121-140. [CrossRef]

25. Grant, T. Keys to Successful Public-Private Partnerships, Canadian Business Review. Can. Bus. Rev. 1996, $23,27-28$.

26. Gentry, B.; Fernandez, L. Evolving public-private partnerships: General themes and urban water examples. In Globalisation and the environment. Perspectives from OECD and Dynamic Non-Members Economies; OECD: Paris, France, 1997; pp. 19-25. Available online: http:/ / www.undp.org/pppue (accessed on 15 August 2020).

27. Zhang, W.; Wang, S.; Tiong, R.; Ting, S.; Ashley, D. Risk management of Shanghai's privately financed Yan'an Donglu tunnels. Eng. Constr. Archit. Manag. 1998, 5, 399-409. [CrossRef]

28. Hambros, S. Public-Private Partnerships for Highways: Experience, Structure, Financing, Applicability and Comparative Assessment: Objective Three, Final Report. In Proceedings of the Council of Deputy Ministers Responsible for Transportation and Highway Safety, Ottawa, Canada, March 1999; Available online: https:/ /www.comt.ca/Reports-e.htm (accessed on 16 August 2020).

29. Hall, D. PPPs: A critique of the Green Paper. 2004. Available online: www.psiru.org/reports/2004 (accessed on 16 August 2020).

30. Patibandla, M.M.; Sethi, R.M. An Analysis of Public-Private Partnerships in Infrastructure of Provision of Public Goods Through E-Governance in India. SSRN Electron. J. 2018, 564. [CrossRef]

31. Thipperudrappa, E. Public Private Partnership and Higher Education System in India: An Economic Analysis. Int. J. Res. Appl. Sci. Eng. Technol. 2017, 5, 1683-1691. [CrossRef]

32. Lakshmanan, L. Public-Private Partnership in Indian Infrastructure Development: Issues and Options; Reserve Bank of India Occasional Papers: Mumbai, India, 2008; p. 29.

33. International Monetary Fund. Public-Private Partnerships. In Prepared by the Fiscal Affairs Department (in Consultation with Other Departments; World Bank and the Inter-American Development Bank: Washington, DC, USA, 2004.

34. Gidman, P.; Blore, I.; Lorentzen, J.; Schuttenbelt, P. Public-Private Partnerships in Urban Infrastructure Services; World Bank-UMP: Washington, DC, USA, 1995; p. 142.

35. Zhang, X. Criteria for Selecting the Private-Sector Partner in Public-Private Partnerships. J. Constr. Eng. Manag. 2005, 131, 631-644. [CrossRef]

36. Ossman, S.A. Private Sector Partnership in Public Service Sector between Theory and Application; Dar Pharos: Alexandria, Egypt, 2019.

37. Li, B.; Akintoye, A. An Overview of Public-Private Partnership. In Public-Private Partnerships; Wiley: Hoboken, NJ, USA, 2008; pp. 1-30.

38. Nikitenko, S.; Goosen, E. The problems and prospects of the public-private partnership in the Russian fuel and energy sector. In Proceedings of the IOP Conference Series: Earth and Environmental Science; IOP Publishing: Bristol, UK, 2017; Volume 53, p. 012018.

39. Van Ham, H.; Koppenjan, J. Building public-private partnerships: Assessing and managing risks in port development. Public Manag. Rev. 2001, 3, 593-598. [CrossRef]

40. Grimsey, D.; Lewis, M.K. Evaluating the risks of public private partnerships for infrastructure projects. Int. J. Proj. Manag. 2002, 20, 107-118. [CrossRef]

41. Choi, J.-H.; Chung, J.; Lee, D.-J. Risk perception analysis: Participation in China's water PPP market. Int. J. Proj. Manag. 2010, 28, 580-592. [CrossRef]

42. Sharma, K.K.; Misra, S.K.; Singla, A.K. Role of Public Private Partnership in Bus Terminals: A Case Study of Punjab. Think India 2019, 22, 116-128. [CrossRef]

43. Muhammad, Z.; Johar, F. Critical success factors of public-private partnership projects: A comparative analysis of the housing sector between Malaysia and Nigeria. Int. J. Constr. Manag. 2018, 19, 257-269. [CrossRef] 
44. Vashalomidze, E.V.; Kokorev, I.A.; Stolyarova, V.A. Development of Public-Private Partnership in the Context of Innovative Modernization of the Economy. Bulletin of Eurasian Science. 2014; Volume 6. Available online: https://cyberleninka.ru/ article/n/razvitie-gosudarsvenno-chastnogo-partnerstva-v-usloviyah-innovatsionnoy-modernizatsii-ekonomiki (accessed on 21 January 2020).

45. Varnavsky, V.G. Mechanisms of Public-Private Partnership in Economic Policy; Mosc. Mgimo Univ.: Moscow, Russia, 2013 ; p. 142.

46. Deryabina, M. Public-Private Partnership: Theory and Practice. Vopr. Ekon. 2008, 8, 61-77. [CrossRef]

47. Kholodnaya, N.D. Public-Private Partnership-A New Type of Relations in the RUSSIAN Economy. Issues of State and Municipal Management. 2009. Volume 2. Available online: https://cyberleninka.ru/article/n/gosudarstvenno-chastnoe-partnerstvonovyy-tip-otnosheniy-v-rossiyskoy-ekonomike (accessed on 28 September 2020).

48. Kochetkova, S.A.; Moiseeva, I.V. The Structural Model of Public-Private Partnerships in the Country Regional Management; Monography, S.A., Kochetkova, I.V., Moiseeva, S.A., Kochetkova, M., Eds.; Publisher-House of the Academy of Natural Sciences: Philadelphia, PA, USA, 2016; p. 160.

49. Kasavin, I.T. Encyclopedia of Epistemology and Philosophy of Science; Kanon+ Publishing House, Rehabilitation NGO: Moscow, Russia, 2009; p. 1248.

50. Hall, D. Why Public-Private Partnerships Don't Work: The Many Advantages of the Public Alternative. Public Services International Research Unit, University of Greenwich. London. 2015. Available online: http:/ /www.world-psi.org/sites/default/ files/rapport_eng_56pages_a4_lr.pdf (accessed on 28 April 2021).

51. Gunatilake, H.; Carangal-San Jose, M.J.F. Privatization Revisited: Lessons from Private Sector Participation in Water Supply and Sanitation in Developing Countries; ERD Working Paper Series No. 115; Asian Development Bank: Mandaluyong City, Philippines, 2008; p. 115. Available online: https://www.adb.org/sites/default/files/publication/28218/wp115.pdf (accessed on 27 April 2021).

52. Gassner, K.; Popov, A.A.; Pushak, N. Does Private Sector Participation Improve Performance in Electricity and Water Distribution? World Bank Publications, 2009. Available online: https:/ / openknowledge.worldbank.org/handle/10986/6605 (accessed on 28 April 2021).

53. Engel, E.; Fischer, R.; Galetovic, A. The basic public finance of public-private partnerships. J. Eur. Econ. Assoc. 2013, 11, 83-111. [CrossRef]

54. IMF. Public-Private Partnerships, Government Guarantees and Fiscal Risk. Fiscal Affairs Department, Washington, DC, 2016. Available online: https://www.imf.org/External/Pubs/NFT/2006/ppp/eng/ppp.pdf (accessed on 28 April 2021).

55. Roig, J.; Soriano, J.M. Public-Private Partnership for Real Estate Projects: Current Framework and New Trends. Euro-American Association of Economic Development Studies: Regional and Sectoral Economic Studies. Available online: https://upcommons. upc.edu/bitstream/handle/2117/27157/eers15112.pdf?sequence=1 (accessed on 27 April 2021).

56. Li, B.; Akintoye, A.; Edwards, P.J.; Hardcastle, C. Critical success factors for PPP/PFI projects in the UK construction industry. Constr. Manag. Econ. 2005, 23, 459-471. [CrossRef]

57. Andersen, A. Enterprise LSE. Value for Money Drivers in the Private Financial Initiative, the Treasury Task Force. London 2000, $15,21-23$.

58. Frilet, M. Some Universal Issues in BOT Projects for Public Infrastructure. Int. Constr. Law Rev. 1997, 14, 499-512.

59. Andr'es, L.A.; Schwartz, J.; Guasch, J.L. Uncovering the Drivers of Utility Performance: Lessons from Latin America and the Caribbean on the Role of the Private Sector, Regulation, and Governance in the Power, Water, and Telecommunication Sectors; The World Bank: Washington, DC, USA, 2013.

60. Mollisi, V. The Impact of Public-Private Partnerships on productivity of the Italian District Heating industry; Working Paper: 2016. Available online: https:/ / econ.au.dk/fileadmin/Economics_Business/Research/Seminars/2016/draft2-mod.pdf (accessed on 27 April 2021).

61. Fabre, A.; Straub, S. The Economic Impact of Public Private Partnerships (PPPs) in Infrastructure, Health and Education: A Review. Toulouse School of Economics; Working paper: 2019. Available online: https:/ /www.tse-fr.eu/sites/default/files/TSE/documents/ doc/wp/2019/wp_tse_986.pdf (accessed on 27 April 2021).

62. Patrinos, H.A.; Barrera-Osorio, F. The Role and Impact of Public-Private Partnerships in Education; Technical Report: Education Section, Human Development; World Bank: Washington, DC, USA, 30 March 2009; Available online: https://gsdrc.org/documentlibrary/the-role-and-impact-of-public-private-partnerships-in-education/ (accessed on 10 February 2020).

63. McCarthy, S.C.; Tiong, R.L.K. Financial and contractual aspects of build-operate-transfer projects. Int. J. Proj. Manag. 1991, 9 , 222-227. [CrossRef]

64. Akintoye, A.; Beck, M. Policy, Finance \& Management for Public-Private Partnerships; Akintoye, A., Beck, M., Eds.; Blackwell Publishing Ltd.: London, UK, 2009; 275p.

65. Hart, O.D. Incomplete Contracts and Public Ownership: Remarks, and an Application to Public-Private Partnerships. SSRN Electron. J. 2002, 113, 69-76. [CrossRef]

66. Martimort, D.; Pouyet, J. To build or not to build: Normative and positive theories of public-private partnerships. Int. J. Ind. Organ. 2008, 26, 393-411. [CrossRef]

67. Andres, L. The impact of Privatization on Firms in the Infrastructure Sector in Latin American Countries. Ph.D. Thesis, University of Chicago, Chicago, IL, USA, 2004. 
68. Hall, D. Privatization, multinationals and corruption, Development in Practice Volume 9, Number 5, November 1999. Available online: http:/ / www.psiru.org/reports/9909-U-U-Corrup.doc (accessed on 27 April 2021).

69. Water and Power: The French Connection. Available online: http://www.publicintegrity.org/water/report.aspx?aid=4 (accessed on 28 April 2021).

70. Greve, C.; Ejersbo, N. When Public-Private Partnerships Fail-The extreme case of the NPM-Inspired Local Government of Farum in Denmark. In Nordisk Kommunalforskningskonference 29 November-1 December 2002, Odense, Denmark. Available online: https:/ / www.semanticscholar.org/paper/WHEN-PUBLIC-PRIVATE-PARTNERSHIPS-FAIL-THE-EXTREME-GreveEjersbo/98b2908f6c76f2742715ed001855fc89099fb921 (accessed on 27 April 2021).

71. PPP Infrastructure and Power Projects most Prone to Corruption. Economic Times. 3 January 2013. Available online: http:/ / articles.economictimes.indiatimes.com/2013-06-03/news/39714786_1_public-procurement-bill-corruption-private-partners (accessed on 28 April 2021).

72. Grimsey, D.; Lewis, M. Public Private Partnerships: The Worldwide Revolution in Infrastructure Provision and Project Finance; Edward Elgar Publishing Ltd.: Cheltenham, UK, 2007; p. 267.

73. Over the Past Year oil Refineries Signed 10 Agreements on Modernization with the Ministry of Energy. Oil and Capital. Available online: https: / / oilcapital.ru/news/regulation/22-07-2020/za-minuvshiy-god-npz-zaklyuchili-s-minenergo-10-soglasheniyo-modernizatsii (accessed on 10 August 2020).

74. Koptev, V.Y.; Kopteva, A.V.; Poddubniy, D.A. Increase in Energy Efficiency of Oil and Gas Companies by Perfecting of Management Systems. In Proceedings of the 2019 IEEE Conference of Russian Young Researchers in Electrical and Electronic Engineering (EIConRus), Saint Petersburg and Moscow, Russia, 28-31 January 2019; pp. 548-552.

75. Trachuk, S.S. The role of public-private partnership projects in the development of the Russian economy. Financ. Res. 2007, 4, 76-82.

76. Kalgina, I.S. Models for assessment of public-private partnership projects in subsurface management. J. Min. Inst. 2017, 224, 247-254. [CrossRef]

77. Timchuk, O.G. Public-Private Partnership in the Innovative Activity of Housing and Communal Services; Emporia State University: Emporia, KS, USA, 2013; p. 20.

78. Reishahrit, E.I. Specific features of energy efficiency management at enterprises of oil processing industry. J. Min. Inst. 2016, 219, 490-497.

79. Molodtsov, K. Oil refining: In Response to Challenges. Oil and Gas Vertical. 2018, Volume 3, pp. 44-46. Available online: http:/ / www.ngv.ru/upload/iblock/a5a/a5a2feba2acad342773d93313bd01aa6.pdf (accessed on 19 February 2020).

80. Oil Refineries in Russia. Available online: https:// pronpz.ru/neftepererabatyvayushchie-zavody/rossiya.html (accessed on 22 February 2020).

81. Central Dispatch Office of the Fuel and Energy Complex. Available online: http:/ /www.cdu.ru/ (accessed on 11 August 2020).

82. Modernization in the Oil Refining Industry//Federal Antimonopoly Service of the Russian Federation. Available online: https: / / fas.gov.ru/upload/mediaarchive/presentation/2020042016.pdf (accessed on 11 August 2020).

83. General Scheme and Elements of life. Analytical Service Oil and Gas Vertical; Test America: Phoenix, AZ, USA, 2017; Volume 3-4, pp. $10-11$.

84. Alexandrova, O.A.; Nizamova, G.Z. Evaluation of the Effectiveness of Investment Projects in the Oil and Gas Industry using Public-Private Partnership Mechanisms. Bull. Eurasian Sci. 2017, 2. Available online: https://cyberleninka.ru/article/n/otsenkaeffektivnosti-investitsionnyh-proektov-v-neftegazovoy-otrasli-s-ispolzovaniem-mehanizmov-gosudarstvenno-chastnogo (accessed on 10 September 2020).

85. Gabdullina, E.I. Evaluation of the effectiveness of PPP as a mechanism of interaction between government and business. In Modern Problems of Science and Education; Academy of Natural Sciences Ltd.: Moscow, Russia, 2012; Volume 2, pp. 54-58.

86. Investment Climate in Russia: Opinion of Foreign Investors. Available online: https: / fiac.ru/pdf/EY-investment-climate-inrussia-2015-rus.pdf (accessed on 12 August 2020).

87. World Oil Outlook 2045. Available online: https://www.opec.org/opec_web/en/publications/340.htm (accessed on 14 April 2021).

88. Kozlov, D. Rosneft Is in No Hurry to Refine; Kommersant Newspaper: Moscow, Russia, 2021; Volume 91, p. 1.

89. Ministry of Energy of the Russian Federation. Available online: https:/ / minenergo.gov.ru/ (accessed on 10 August 2020).

90. Abramovich, B.N.; Sychev, Y.A. Energy Safety of Technological Processes of Oil Extraction Neftyanoe Khozyaystvo; Oil Industry: Moscow, Russia, 2016; Volume 9, pp. 120-123.

91. Karpikov, A.V.; Aliev, R.I.; Babyr, N.V. An analysis of the effectiveness of hydraulic fracturing at YS1 of the Northern field. IOP Conf. Ser. Mater. Sci. Eng. 2020, 952, 012036. [CrossRef]

92. Efficiency of Refining in Russia, Europe and the USA. Portal Neftegaz.ru. Available online: https://neftegaz.ru/analisis/view / 8485-Glubina-pererabotki-nefti-v-Rossii-Evrope-i-SShA (accessed on 28 February 2020).

93. Privalov, N.G.; Privalova, S.G. Problems of mineral tax computation in the oil and gas sector. J. Min. Inst. 2017, $224,255-262$. [CrossRef]

94. Oil Tax Maneuvers: What's Next? VYGON Consulting-May 2015. Available online: https://vygon.consulting/upload/iblock/ 2af/vygon_consulting_taxmaneuvers.pdf (accessed on 28 February 2020). 
95. Federal State Statistics Service. Available online: https://rosstat.gov.ru/bgd/free/B04_03/IssWWW.exe/Stg/d05/159.htm (accessed on 10 October 2020).

96. Energy Strategy of Russia for the Period up to 2030. Available online: https:/ / minenergo.gov.ru/node/15357 (accessed on 28 February 2020).

97. Law of the Russian Federation of 21 May 1993 N 5003-I «On the Customs Tariff» (as Amended and Supplemented). Available online: http:/ / base.garant.ru/10101366/ (accessed on 28 February 2020).

98. Tax Code of the Russian Federation. Available online: http://www.consultant.ru/document/cons_doc_LAW_19671/ (accessed on 7 October 2020).

99. Technical Regulations “On Requirements for Automobile and Aviation Gasoline, Diesel and Marine Fuel, Jet Fuel and Fuel Oil". Approved by Decree of the Government of the Russian Federation of 27 February 2008 N 118. Available online: https: / / base.garant.ru/192858 / (accessed on 28 February 2020).

100. Experts Called the Situation in Russia Unfavorable for Oil Refining. Internet Newspaper Lenta.ru. 20 May 2019. Available online: https:/ /lenta.ru/news/2019/05/20/neftehim/ (accessed on 28 February 2020).

101. Struchkov, I.; Rogachev, M. The challenges of waxy oil production in a Russian oil field and laboratory investigations. J. Pet. Sci. Eng. 2018, 163, 91-99. [CrossRef]

102. National Center for Public-Private Partnership. Available online: https:/ /pppcenter.ru (accessed on 28 February 2020).

103. Energy Strategy of Russia for the Period 2035. Available online: https://minenergo.gov.ru/node/1026 (accessed on 5 September 2020).

104. Target 17.17: Public, Private and Civil Partnerships. Development and Globalization: Facts and Figures. United Nations (UNCTAD), 2016. Available online: https:/ / stats.unctad.org/Dgff2016/partnership/goal17/target_17_17.html (accessed on 27 April 2021).

105. Forecast of the Long-Term Socio-Economic Development of the Russian Federation for the Period up to 2030 (Developed by the Ministry of Economic Development of the Russian Federation). Available online: https://consultant.ru/document/cons_doc_ LAW_144190/ (accessed on 16 April 2021).

106. Mistakes of Public-Private Partnership. Available online: https://rb.ru/opinion/6-mistakes-and-cases/ (accessed on 12 August 2020).

107. Krugman, P. Privatization Can Lead to Patronage and Corruption; Sacramento Bee: Sacramento, CA, USA, 2012.

108. See Overview of Energy in Africa 2013, and Global Experience with Electricity Liberalization 2009. Available online: www.psiru. org (accessed on 28 April 2021). 